\title{
PENGARUH PENDIDIKAN KESEHATAN MELALUI MEDIA ULAR TANGGA PHBS DI SEKOLAH TERHADAP PENINGKATAN PENGETAHUAN DAN SIKAP SISWA DI SD NEGERI MARGAMULYA KECAMATAN SINGAPARNA KABUPATEN TASIKMALAYA TAHUN 2016
}

\author{
Sinta Fitriani, SKM,MKM dan Fenty Agustini, SST, M.Kes \\ (taniesa1571@,gmail.com)
}

\section{A. ABSTRAK}

Permasalahan kesehatan pada anak sekolah diantaranya penyakit karies gigi pada anak usia sampai 12 tahun sebesar 74,4\% (Depkes, 2012). Hampir 50-60\% anak-anak di daerah rural menderita penyakit cacing terutama penyakit cacing gelang, cacing kremi, cacing perut, dan cacing tambang. Penyakit ini ditularkan ke anak-anak secara langsung dengan menelan telur cacing yang mengkontaminasi makanan mereka, sedangkan cacing tambang ditularkan dengan cara menerobosnya larva pada kaki penderita yang tidak bersepatu (Soegijanto, 2012).Permasalahan lain adalah hanya $17 \%$ anak usia sekolah yang mencuci tangan menggunakan sabun dengan benar, padahal anak usia tersebut rentan terhadap penyakit seperti diare (Depkes RI, 2012).

Metode penelitian yang digunakan merupakan metode kuantitatif dengan metode quasi experimen desain one-group pre-test post-test. Uji perbedaan dua rata-rata digunakan untuk mengetahui pengaruh hasil pretest sebelum diberikan perlakuan (treatment) dan hasil post-test sesudah diberi perlakuan (treatment). Untuk mengetahui perbedaan dua rata-rata ini menggunakan uji satu pihak (uji t).Sampel dalam penelitian ini adalah seluruh siswa kelas 2-4SD Negeri Margamulya sebanyak 111 orang. Variabel yang diukur adalah pengetahuan sebelum dan sesudah pendidikan kesehatan melalui permainan ular tangga. Instrumen yang digunakan adalah kuesioner serta papan ular tangga ber PHBS di sekolah.

Hasil penelitian menyatakan bahwa Rata rata nilai pengetahuan siswa sebelum adalah 9.94 dengan standar deviasi 1.337. Nilai terendah adalah 7 dan nilai paling tinggi adalah 13 . Rata rata nilai pengetahuan responden tentang PHBS Sekolah sesudah permainan ular tangga adalah 16,6 dengan standar deviasi 1,638. Nilai paling rendah pengetahuan responden adalah 12 dan nilai paling tinggi responden adalah 20. Hasil uji statistik didapatkan nilai $p=0.002$, berarti pada alpha 5\% artinya terdapat perbedaan yang signifikan rata rata nilai sebelum dan sesudah permainan ular tangga PHBS sekolah. Sedangkan rata rata nilai sikap responden sebelum permainan ular tangga adalah 5.06 dengan standar deviasi 0.742. Nilai terendah adalah 2 dan nilai paling tinggi adalah 7. Serta rata rata nilai sikap positif responden adalah 5,13 dengan standar deviasi 0,067. Sedangkan rata rata nilai sikap negatif responden adalah 4,14 dengan standar deviasi 1,069. Hasil uji statistik didapatkan nilai $p=0.001$, berarti pada alpha 5\% artinya terdapat perbedaan yang signifikan rata rata sikap responden sebelum dan sesudah permainan ular tangga PHBS sekolah.

Kata Kunci : Pengetahuan dan sikap siswa, Pendidikan kesehatan, Permainan ular tangga PHBS di sekolah. 


\section{B. Pendahuluan}

PHBS di sekolah adalah upaya untuk memperdayakan siswa, guru, dan masyarakat lingkungan sekolah agar tahu, mau, dan mampu mempraktikkan PHBS dan berperan aktif dalam mewujudkan sekolah sehat. Perilaku hidup bersih dan sehat juga merupakan sekumpulan perilaku yang dipraktikkan oleh peserta didik, guru, dan masyarakat lingkungan sekolah atas dasar kesadaran sebagai hasil pembelajaran, sehingga secara mandiri mampu mencegah penyakit, meningkatkan kesehatannya , serta berperan aktif dalam mewujudkan lingkungan sehat (Depkes RI, 2012).

Pada tahapan usia anak sekolah terdapat beberapa masalah yang mungkin terjadi diantaranya penyakit menular seperti : Demam Berdarah Dengue, Infeksi Tangan Mulut, Campak, Rubela (campak jerman), Cacar Air, Gondong dan infeksi mata (Konjungtivitis Virus). Serta Penyakit Non Infeksi pada Anak Sekolah seperti Alergi, Infeksi Parasit Cacing: (prevalensi penyakit cacingan sebesar 60-70\%), Kasus infeksi cacing gelang (Ascaris lumbricoides) sekitar 25 - 35 persen dan cacing cambuk (Trichuris trichiura) $65-75$ persen. Resiko tertinggi terutama kelompok anak yang mempunyai kebiasaan defekasi disaluran air terbuka dan sekitar rumah, makan tanpa cuci tangan, dan bermain-main di tanah yang tercemar telur cacing tanpa alas kaki. Penyakit karies gigi pada anak usia sampai 12 tahun sebesar 74,4\% (Depkes, 2012). Serta Hampir $50-60 \%$ anak-anak di daerah rural menderita penyakit cacing terutama penyakit cacing gelang, cacing kremi, cacing perut, dan cacing tambang. Penyakit ini ditularkan ke anak-anak secara langsung dengan menelan telur cacing yang mengkontaminasi makanan mereka, sedangkan cacing tambang ditularkan dengan cara menerobosnya larva pada kaki penderita yang tidak bersepatu (Soegijanto, 2012).Permasalahan lain adalah hanya $17 \%$ anak usia sekolah yang mencuci tangan menggunakan sabun dengan benar, padahal anak usia tersebut rentan terhadap penyakit seperti diare (Depkes RI, 2012).

Untuk meningkatkan kesehatan anak usia sekoah diperlukan upaya sosialisasi kegiatan perilaku hidup bersih dan sehat di sekolah melalui rancangan media pendidikan yang menarik sehingga pesan yang disampaiakan bisa mudah diterima oleh siswa. Hal ini dikarenakan anak sekolah memiliki karakter yang khas dan unik baik secara fisik maupun mental, oleh karena itu strategi dan metode pengajaran yang diterapkan harus sesuai dengan kekhasan anak yaitu dengan strategi bermain sambil belajar atau belajar seraya bermain. Bermain merupakan sarana untuk menggali pengalaman belajar yang sangat berguna untuk anak. Bermain juga dapat menjadi sarana untuk mengembangkan kreativitas dan daya cipta, karena bermain adalah sumber pengalaman dan uji coba. Bermain dari segi pendidikan adalah kegiatan permainan menggunakan alat permainan mendidik serta alat yang bisa merangsang perkembangan aspek kognitif, emosi, sosial, dan fisik yang dimiliki anak.

Permainan ular tangga PHBS di sekolah adalah permainan untuk anak sekolah dengan berbagai pesan sesuai dengan indicator PHBS di sekolah seperti perilaku personal hygiene, keutamaan olah raga teratur, larangan merokok dan napza, pemberantasan sarang nyamuk, jamban sehat, air 
bersih, cuci tangan pake sabun, membuang sampah, jajanan sehat serta pengukuran berat badan dan tinggi badan. Permainan ular tangga adalah permainan papan untuk anakanak yang dimainkan oleh 2 orang atau lebih. Papan permainan dibagi dalam kotak-kotak kecil dan di beberapa kotak digambar sejumlah "tangga" atau "ular yang menghubungkannya dengan kotak lain. Permainan ini diciptakan pada tahun 1870 . Setiap pemain mulai dengan bidaknya di kotak pertama (biasanya kotak di sudut kiri bawah) dan secara bergiliran melemparkan dadu. Bidak dijalankan sesuai dengan jumlah mata dadu yang muncul. Bila pemain mendarat di ujung bawah sebuah tangga, mereka dapat langsung pergi ke ujung tangga yang lain. Bila mendarat di kotak dengan ular, mereka harus turun ke kotak di ujung bawah ular. Pemenang adalah pemain pertama yang mencapai kotak terakhir. (Wikipedia : 2010)

Tujuan dari penelitian ini adalah mengetahui perbedaan pengetahuan siswa tentang PHBS di sekolah sebelum dan sesudah permainan. Berdasarkan latar belakang yang telah dipaparkan maka diarasakan perlu dilakukan penelitian mengenai " pengaruh pendidikan kesehatan melalui media ular tangga PHBS di sekolah terhadap peningkatan pengetahuan dan sikap siswa di SD Negeri Margamulya Kecamatan Singaparna Kabupaten Tasikmalaya tahun 2015"

\section{METODE PENELITIAN}

Metode penelitian yang digunakan merupakan metode kuantitatif dengan metode quasi Experimental Design yaitu one-group pre-test posttest.Desain ini merupakan pengembangan dari desain one-shoot case study (Studi Kasus Satu Tembakan) di mana dalam design penelitian ini terdapat pre-test sebelum diberi perlakuan.Variabel yang diukur meliputi pengetahuan dan sikap siswa tentang perilaku hidup bersih dan sehat di sekolah sebelum dan sesudah intervensi pendidikan melalui permainan ular tangga. Penelitian ini menggunakan uji one sample t-test. Uji ini bertujuan untuk menentukan apakah suatu nilai tertentu (yang diberikan sebagai pembanding) berbeda secara nyata dengan rata-rata (mean) sample.

Teknik pengambilan sampel yang dipakai dalam penelitian ini adalah cluster sampling, yaitu teknik pengambilan bukan berdasarkan pada individual, tetapi lebih berdasarkan pada kelompok, daerah atau kelompok subjek yang secara alami berkumpul bersama. Sampel dari penelitian in adalah siswa kelas 2 - 4 SDN Margamulya Kecamatan Singaparna Kabupaten Tasikmalaya sejumlah 111 orang. Pengambilan sampel ini karena populasi di asumsikan berdistribusi normal dan dalam keadaan homogen.

Instrumen penelitian yang digunakan adalah 20 pertanyaan untuk pengetahuan PHBS sekolah dengan mengacu pada indikator PHBS di sekolah serta 10 pernyataan sikap. Instrumen telah dilakukan uji validitas terhadap 30 siswa TPA Alhidayah kelas $2-4$ SD. Dengan hasil nilai $r$ hitung $>$ dari $r$ tabel. Serta uji realibilitas dengan nilai croncbach alpha $>$ dari $r$ Tabel.

Analisis ini menggunakan uji satu sampel untuk rata-rata (one sample $\mathrm{t}$ test). Dengan uji tersebut akan diketahui apakah ada pengaruh antara nilai ratarata pre-test dan post-test kelas eksperimen.

Analisis Data Tahap Awal

Metode untuk menganalisis data adalah sebagai berikut:

Uji normalitas digunakan untuk mengolah data nilai pre-test dalam menentukan apakah kelas yang telah diuji berdistribusi normal atau tidak. 
Rumus pengujian ini dikenal dengan

Chi Kuadrat. Metode untuk menganalisis data nilai akhir setelah diberi perlakuan adalah Untuk langkah-langkah pengujian normalitas data tahap akhir sama dengan langkah-langkah uji normalitas pada analisis data tahap awal. Uji normalitas digunakan untuk mengolah data nilai post-test dalam menentukan apakah kelas yang telah diuji berdistribusi normal atau tidak Uji perbedaan dua rata-rata digunakan untuk mengetahui pengaruh hasil pre-test sebelum diberikan perlakuan (treatment) dan hasil post-test sesudah diberi perlakuan (treatment). Untuk mengetahui perbedaan dua ratarata ini menggunakan uji satu pihak (uji t)

\section{HASIL PENELITIAN}

1. Gambaran pengetahuan siswa tentang PHBS sebelum permainan media ular tangga.

Berdasarkan hasil penelitian dapat dilihat sebagai berikut :

Distribusi Frekwensi pengetahuan responden sebelum permainan ular tangga PHBS sekolah di SDN Margamulya Kecamatan Singaparna Kabupaten Tasikmalaya tahun 2016

\begin{tabular}{|c|c|c|c|}
\hline Variabel & Mean & SD & $\begin{array}{c}\text { Min - } \\
\mathbf{m a x}\end{array}$ \\
\hline Pengetahuan sebelum & 9.94 & 1.337 & $7-13$ \\
\hline & & & \\
\hline
\end{tabular}

Berdasarkan hasil analisis didapatkan rata rata nilai pengetahuan siswa sebelum adalah 9.94 dengan standar deviasi 1.337. Nilai terendah adalah 7 dan nilai paling tinggi adalah 13 .

Distribusi Frekwensi kategori pengetahuan responden sebelum permainan ular tangga PHBS sekolah di SDN Margamulya Kecamatan Singaparna Kabupaten Tasikmalaya tahun 2016

\begin{tabular}{|l|l|c|c|}
\hline No & Pengetahuan & F & \% \\
\hline 1 & Baik & 0 & 0 \\
2 & Cukup & 35 & 31.5 \\
3 & Kurang & 76 & 68.5 \\
& & & \\
\hline & Jumlah & $\mathbf{1 1 1}$ & $\mathbf{1 0 0}$ \\
\hline
\end{tabular}

Berdasarkan tabel diatas didapatkan bahwa tingkat pengetahuan responden tentang PHBS Sekolah mayoritas kategori kurang yaitu 68.5\% 
Distribusi pertanyaan paling banyak dijawab benar tertera dalam tabel berikut ini :

\begin{tabular}{|l|l|c|c|}
\hline No & \multicolumn{1}{|c|}{ Pertanyaan } & F & $\mathbf{\%}$ \\
\hline 1 & Kebiasaan mandi & 103 & 92.7 \\
2 & Kebiasaan keramas & 22 & 19.8 \\
3 & Waktu gosok gigi & 18 & 16,2 \\
4 & Pemeriksaan gigi & 104 & 93,6 \\
5 & Cuci tangan dengan air mengalir & 80 & 72 \\
6 & Maanfaat cuci tangan & 90 & 86,4 \\
7 & Ciri air bersih & 51 & 45,9 \\
8 & Keutamaan olah raga & 79 & 71,1 \\
9 & Keutamaan sayuran hijau & 91 & 87,3 \\
10 & Keutamaan makan buah & 73 & 65.7 \\
11 & Kebiasaan sarapan & 97 & 87.3 \\
12 & Hal yang diperhatikan sebelum jajan & 8 & 7,2 \\
13 & Akibat jajan & 21 & 18,9 \\
14 & Tempat jentik nyamuk & 29 & 26,1 \\
15 & Kebiasaan gantung pakaian bekas & 33 & 29,7 \\
16 & 3 M (kubur barang bekas) & 51 & 45,9 \\
17 & 3M (Penampungan air) & 44 & 39,6 \\
18 & Jamban sehat & 35 & 31,5 \\
19 & Cegah cacingan & 52 & 46,8 \\
20 & Ukur TB/BB & 16 & 14,4 \\
& & & \\
\hline
\end{tabular}

Berdasarkan tabel diatas responden mayoritas menjawab dengan benar tentang pemeriksaan gigi harus dilakukan 6 bulan sekali yaitu 93,6\% serta kebiasaan mandi minimal 2 kali sehari yaitu $92,7 \%$.

Sedangkan untuk pertanyaan yang paling banyak dijawab salah yaitu tentang hal hal yang harus diperhatikan sebelum jajan serta pengukuran Berat badan dan tinggi badan secara rutin serta waktu yang tepat untuk menggosok gigi.

\section{Gambaran pengetahuan siswa tentang PHBS sesudah permainan media ular} tangga.

Berdasarkan hasil penelitian didapatkan bahwa nilai rata rata pengetahuan responden tentang PHBS sekolah adalah sebagai berikut :

\section{Distribusi nilai pengetahuan responden tentang PHBS sekolah setelah permainan ular tangga di SD Margamulya Kecamatan Singaparna Kabupaten Tasikmalaya tahun 2016}

\begin{tabular}{|c|c|c|c|c|}
\hline Variabel & Mean & $\begin{array}{c}\text { Media } \\
\mathbf{n}\end{array}$ & SD & Min - Max \\
\hline Pengetahuan post test & 16.6 & 17 & 1.638 & $12-20$ \\
\hline & & & & \\
\hline
\end{tabular}

Berdasarkan tabel diatas didapatkan bahwa rata rata nilai pengetahuan responden tentang PHBS Sekolah adalah 16,6 dengan standar deviasi 1,638. Nilai paling rendah pengetahuan responden adalah 12 dan nilai paling tinggi responden adalah 20 . 


\section{Perbedaan pengetahuan sebelum dan sesudah permainan ular tangga PHBS}

sekolah.

Berdasarkan hasil penelitian didapatkan bahwa perbedaaan pengetahuan responden sebelum dan sesudah permainan ular tangga PHBS sekolah tercantum dalam tabel berikut ini :

Perbedaan pengetahuan sebelum dan sesudah permainan ular tangga PHBS di SDN Margamulya Kecamatan Singaparna Kabupaten Tasikmalaya tahun 2016

\begin{tabular}{|c|c|c|c|c|c|}
\hline $\begin{array}{c}\text { Pengetah } \\
\text { uan }\end{array}$ & Mean & SD & SE & P value & N \\
\hline Sebelum & 9.94 & 1.337 & 0.127 & 0.000 & 111 \\
\hline Sesudah & 16.66 & 1.638 & 0.155 & & \\
\hline
\end{tabular}

Berdasarkan tabel 5.6 didapatkan rata rata nilai pengetahuan sebelum diberikan permainan ular tangga adalah 2.68 dengan standar deviasi 0.467 . Sedangkan nilai rata rata pengetahuan siswa setelah permainan ular tangga adalah 16.66 dengan standar deviasi 1.638.

Hasil uji statistik didapatkan nilai $\mathrm{p}=0.000$, berarti pada alpha $5 \%$ artinya terdapat perbedaan yang signifikan rata rata nilai sebelum dan sesudah permainan ular tangga PHBS sekolah.

\section{Sikap Siswa tentang PHBS di sekolah}

a. Gambaran sikap siswa tentang PHBS sebelum permainan media ular tangga.

Gambaran sikap responden tentang PHBS sekolah tertera pada tabel berikut ini :

Distribusi Frekwensi sikap responden sebelum permainan ular tangga

PHBS sekolah di SDN Margamulya Kecamatan Singaparna Kabupaten Tasikmalaya tahun 2016

\begin{tabular}{|c|c|c|c|}
\hline Variabel & Mean & SD & Min - max \\
\hline Sikap sebelum & 5.06 & 0.742 & $2-7$ \\
\hline
\end{tabular}

Berdasarkan hasil analisis didapatkan rata rata nilai sikap responden sebelum permainan ular tangga adalah 5.06 dengan standar deviasi 0.742 . Nilai terendah adalah 2 dan nilai paling tinggi adalah 7.

Distribusi pernyataan paling banyak dijawab setuju dan tidak setuju tertera dalam tabel berikut ini : 


\begin{tabular}{|l|l|c|c|}
\hline No & Pernyataan & F & \% \\
\hline 1 & Cuci tangan harus di air yang mengalir & 107 & 97.2 \\
2 & Bahaya rokok bagi kesehatan & 47 & 42.7 \\
3 & Narkoba bikin percaya diri & 23 & 20.9 \\
4 & Buang sampah pada tempatnya & 109 & 99.0 \\
5 & Kadaluarsa harus dilihat sebelum jajan & 105 & 95.4 \\
6 & Frekwensi menguras bak mandi & 44 & 40 \\
7 & Penyebab penyakit demam berdarah & 26 & 23.63 \\
8 & Jamban sehat itu yang wangi & 1 & 0.9 \\
9 & Frekwensi gosok gigi & 98 & 89.09 \\
10 & Obesitas itu gizi baik & 2 & 1.8 \\
\hline
\end{tabular}

Berdasarkan sebaran pernyataan diatas didapatkan bahwa mayoritas responden menjawab dengan setuju tentang membuang sampah harus pada tempatnya serta mencuci tangan harus di air yang mengalir. Sedangkan untuk pernyataan yang salah dijawab setuju adalah tentang jamban sehat itu jamban yang wangi dan gemuk menandakan gizi baik.

\section{b. Perbedaan sikap siswa sebelum dan sesudah permainan ular tangga}

Berdasarkan hasil penelitian didapatkan bahwa perbedaaan pengetahuan responden sebelum dan sesudah permainan ular tangga PHBS sekolah tercantum dalam tabel berikut ini :

Tabel 5.8

Perbedaan sikap sebelum dan sesudah permainan ular tangga PHBS di SDN Margamulya Kecamatan Singaparna Kabupaten Tasikmalaya tahun 2016

\begin{tabular}{|l|c|c|c|c|c|}
\hline Sikap & Mean & SD & SE & P value & N \\
\hline Sebelum & 5.06 & 0.742 & 0.070 & 0.001 & 111 \\
\hline Sesudah & 8.57 & 0.770 & 0.073 & & \\
\hline
\end{tabular}

Berdasarkan tabel 5.8 didapatkan bahwa rata rata nilai sikap sebelum permainan ular tangga adalah 5.06 dengan standar deviasi 0.742. Sedangkan rata rata nilai sikap sesudah permainan ular tangga adalah 8.57 dengan standar deviasi 0.770 . Hasil uji statistik didapatkan nilai $\mathrm{p}=0.001$, berarti pada alpha $5 \%$ artinya terdapat perbedaan yang signifikan rata rata sikap responden sebelum dan sesudah permainan ular tangga PHBS sekolah. 


\section{E. PEMBAHASAN}

\section{Pengetahuan tentang PHBS sekolah}

Berdasarkan hasil analisis didapatkan rata rata nilai pengetahuan responden tentang PHBS sekolah sebelum permainan ular tangga adalah

9.94 dengan standar deviasi 1.337. Nilai terendah adalah 7 dan nilai paling tinggi adalah 13. Hal ini menunjukan bahwa rata rata nilai pengetahuan responden masih dalam kategori kurang.

Hal ini sesuai teori bahwa pengetahuan adalah hasil penginderaan manusia, atau hasil tahu seseorang terhadap objek melalui indera yang dimilikinya (mata, hidung, telinga, dan sebagainya) (Notoatmodjo, 2010).

Indikator pengetahuan PHBS sekolah meliputi : menjaga kesehatan dan kerapihan rambut, memakai pakaian bersih dan rapih, memelihara kuku, olah raga yang teratur, tidak merokok, memberantas jentik nyamuk, mennggunakan jamban sehat, menggunakan air bersih, cuci tangan pakai sabun di air yang mengalir, buang sampah pada tempatnya, jajan di kantin sekolah serta memeriksa $\mathrm{BB} / \mathrm{TB}$ secara teratur. (Depkes RI : 2007)

Pengetahuan merupakan

domain penting dalam pembentukan perilaku. Perilaku hidup bersih dan sehat di sekolah turut ditunjang dengan pengetahuan siswa yang baik. Nilai rata rata pengetahuan siswa yang rendah menginidkasikan bahwa perilaku hidup bersih dan sehat di sekolah belum terwujud.

Perilaku Hidup Bersih dan Sehat (PHBS) adalah bentuk perwujudan paradigma sehat dalam budaya perorangan, keluarga, dan masyarakat yang berorientasi sehat, bertujuan untuk meningkatkan, memelihara, dan melindungi kesehatannya baik fisik, mental, spiritual, maupun sosial. Selain itu juga program perilaku hidup bersih dan sehat bertujuan memberikan pengalaman belajar atau menciptakan suatu kondisi bagi perorangan, kelompok, keluarga, dengan membuka jalur komunikasi, informasi, dan edukasi untuk meningkatkan pengetahuan, sikap, dan perilaku sehingga masyarakat sadar, mau, dan mampu mempraktikkan perilaku hidup bersih dan sehat melalui pendekatan pimpinan (advocacy), bina suasana (social support), dan pemberdayaan masyarakat (empowerment). Dengan demikian masyarakat dapat mengenali dan mengatasi masalahnya sendiri terutama pada tatanannya masing-masing (Depkes RI, 2002).

Perilaku Hidup Bersih dan Sehat adalah sekumpulan perilaku yang dipraktikkan atas dasar kesadaran sebagai hasil pembelajaran yang menjadikan individu/kelompok dapat menolong dirinya sendiri dalam bidang kesehatan dan berperan aktif dalam mewujudkan derajat kesehatan masyarakat (Dinkes Jabar, 2010).

Berdasarkan tabel diatas responden mayoritas menjawab dengan benar tentang pemeriksaan gigi harus dilakukan 6 bulan sekali yaitu 93,6\% serta kebiasaan mandi minimal 2 kali sehari yaitu $92,7 \%$.

Pentingnya siswa anak sekolah memahami tentang pemeriksaan gigi secara teratur harus dilakukan setiap enam bulan sebagaimana direkomendasikan oleh American Dental Hygienists Association. Pemeriksaan gigi yang teratur penting karena alasan sebagai berikut: Untuk memperkirakan seberapa sehat gigi dan gusi Anda dan karenanya mengobati penyakit, untuk mengevaluasi risiko pembusukan gigi dan penyakit gusi sehingga perkiraan pencegahan akan dilakukan sebelum penyakit menjadi lebih sulit diobati dan diatasi, untuk mengatasi bengkak dalam semua bagian mulut Anda termasuk gusi dan pengeroposan tulang serta untuk mengidentifikasi tanda-tanda yang tidak biasa dalam rongga mulut Anda seperti 
perubahan warna mukosa mulut atau leukoplakia (bercak putih dan abu-abu di dalam mulut) yang dapat menjadi tanda kelainan yang lebih serus seperti infeksi.

Kulit mempunyai peranan yang penting dalam menjaga dan memelihara kesehatan tubuh agar tetap sehat. Oleh sebab itu, kesehatan kulit harus selalu terjaga dengan baik. Untuk itu, kulit harus selalu dipelihara kesehatannya. Cara membersihkan kulit secara keseluruhan umumnya dilakukan dengan mandi, karena mandi berguna untuk menghilangkan kotoran yang melekat pada permukaan kulit : menghilangkan bau keringat, merangsang peredaran darah dan syaraf, serta mengembalikan kesegaran tubuh (Ananto, 2006).

Menurut Tim Pembina UKS Prop. Jawa Barat (2004), cara mandi yang baik dan benar meliputi:

1. Mandi sekurang-kurangnya 2 kali sehari (pagi dan sore hari).

2. Seluruh permukaan kulit disiram dengan air yang dipakai untuk mandi.

3. Seluruh permukaan tubuh atau kulit digosok dengan sabun untuk menghilangkan kotoran yang menempel dikulit terutamapada bagian yang berlemak (lipatan telinga, ketiak, lipatan paha, jari kaki atau tangan dan muka) sampai kotoran hilang.

4. Setelah digosok dengan sabun pada seluruh permukaan tubuh atau kulit kemudian disiram dengan air bersih.

5. Keringkan seluruh permukaan tubuh atau kulit dengan handuk pribadi atau milik sendiri yang bersih dan kering.

6. Sesudah mandi memakai pakaian yang bersih.

Sedangkan untuk pertanyaan yang paling banyak dijawab salah yaitu tentang hal hal yang harus diperhatikan sebelum jajan serta pengukuran Berat badan dan tinggi badan secara rutin serta waktu yang tepat untuk menggosok gigi.
Responden mayoritas tidak mengetahui tentang pentingnya melakukan pemantauan status gizi seperti pengukuran Berat badan dan tinggi badan. Mengukur berat dan tinggi badan merupakan salah satu upaya untuk mengetahui pertumbuhan dan perkembangan anak, dengan diketahuinya tingkat pertumbuhan dan perkembangan anak, sedangkan untuk mengetahui pertumbuhan seorang anak normal atau tidak, bisa diketahui melalui cara membandingkan ukuran tubuh anak yang bersangkutan dengan ukuran tubuh anak seusia pada umumnya.

Apabila anak memiliki ukuran tubuh melebihi ukuran rata-rata anak yang seusia pada umumnya, maka pertumbuhannya bisa dikatakan maju. Sebaliknya bila ukurannya lebih kecil berarti pertumbuhannya lambat. Pertumbuhan dikatakan normal apabila ukuran tubuhnya sama dengan ukuran rata-rata anak lain seusianya (Jawapos, 2010).

Pertanyaan lain yang paling banyak dijawab salah yaitu waktu yang tepat saat menggosok gigi. Menggosok gigi sebaiknya Mulut, termasuk lidah dan gigi merupakan sebagian dari alat pencernaan makanan. Gigi, terdiri dari jaringan tulang keras, terdapat paha rahang atas dan rahang bawah. Mulut dan gigi merupakan satu kesatuan karena gigi terdapat dirongga mulut, dengan membersihkan gigi berarti kita selalu membersihkan rongga mulut dari sisa-sisa makanan yang biasanya tertinggal di antara gigi dan gusi. Pada waktu menyikat atau menggosok gigi harus diingat bahwa arah penyikatan yang baik adalah dari gusi kepermukaan gigi, sehingga selain membersihkan gigi juga dapat melakukan pengurutan terhadap gusi. Menggosok gigi juga dapat pula dengan gerakan maju mundur dan pendek-pendek selama 2 menit dan sedikitnya $8 x$ gerakan untuk 
Permukaan gigi yang dipakai untuk mengunyah, setelah selesai disikat kumur-kumur dengan air yang bersih.

Menggosok gigi lebih baik dilakukan setelah selesai makan (makan pagi) dan pada waktu malam ketika akan tidur dengan menggunakan sikat pribadi. Sementara itu, menurut Potter dan Perry (2005), menggosok gigi adalah membersihkan gigi, harus memperhatikan pelaksanaan waktu yang tepat dalam membersihkan gigi. Penggunaan alat yang tepat untuk membersihkan gigi, dan cara yang tepat untuk membersihkan gigi. Oleh karena itu, kebiasaan menggosok gigi merupakan tingkah laku manusia dalam membersihkan gigi dan sisa-sisa makanan yang dilakukan secara terus menerus meliputi kebiasaan pelaksanaan waktu membersihkan gigi, kebiasaan alat yang digunakan dalam membersihkan gigi, dan kebiasaan cara dalam membersihkan gigi.

Kebiasaan menggosok gigi yang baik dapat turut mencegah karies gigi. Wong, Hockenberry, Wilson, Winkelstein, dan Schwartz (2008) mengungkapkan bahwa kebiasaan menggosok gigi yang baik merupakan cara paling efektif untuk mencegah karies gigi. Menggosok gigi dapat menghilangkan plak atau deposit bakteri lunak yang melekat pada gigi yang menyebabkan karies gigi (Wong, Hockenberry, Wilson, Winkelstein, \& Schwartz, 2008). Oleh karena itu kebiasaan menggosok gigi yang baik dapat turut mencegah karies gigi Kebiasaan menggosok gigi yang baik di malam hari adalah setelah makan malam atau sebelum tidur malam. Kebiasaan anak menggosok gigi malam hari adalah tingkah laku yang dilakukan terus menerus dalam membersihkan gigi sebelum tidur malam yang memperhatikan pelaksanaan menggosok gigi sebelum tidur malam, alat menggosok gigi, dan cara menggosok gigi.

Menggosok gigi yang efektif adalah sebelum tidur malam (Potter dan Perry, 2005). Dari uraian diatas dapat disimpulkan bahwa kebiasaan menggosok gigi malam hari adalah tingkah laku yang dilakukan terus menerus dalam membersihkan gigi sebelum tidur malam yang memperhatikan waktu menggosok gigi, dan cara menggosok gigi. Waktu menggosok gigi yang baik adalah setelah makan pagi dan sebelum tidur malam. Cara menggosok gigi juga harus memperhatikan bentuk sikat gigi, peralatan menggosok gigi, dan cara menggosok gigi yang baik dan benar.

Dibutuhkan berbagai upaya untuk meningkatkan pengetahuan siswa tentang PHBS sekolah seperti penyuluhan dan konseling yang terintegrasi dalam program UKS dengan metode yang disenangi oleh anak usia sekolah. Selain itu dibutuhkan dukungan dari guru, orang tua serta petugas kesehatan dalam membentuk perilaku hidup bersih dan sehat di sekolah.

\section{Sikap tentang PHBS sekolah}

Berdasarkan hasil analisis
didapatkan rata rata nilai sikap responden sebelum permainan ular tangga adalah 5.06 dengan standar deviasi 0.742 . Nilai terendah adalah 2 dan nilai paling tinggi adalah 7 .

Berdasarkan hasil penelitian didapatkan bahwa rata rata sikap responden terhadap PHBS sekolah masih di bawah rata rata. Hal ini seseuai dengan teori yang menyatakan bahwa salah satu faktor yang berpengaruh terhadap perilaku adalah sikap. Dimana sikap adalah reaksi atau respon seseorang yang masih tertutup terhadap suatu stimulus atau obyek (Soekidjo N, 2003).

Newcomb dalam Notoatmodjo (2003) menyatakan bahwa sikap merupakan kesiapan atau kesediaan 
untuk bertindak, dan bukan merupakan pelaksanan motif tertentu. Sikap belum merupakan suatu tindakan atau aktifitas, akan tetapi adalah merupakan "predisposisi" tindakan atau perilaku. Sikap masih merupakan reaksi tertutup, bukan merupakan reaksi terbuka. Sikap positif dapat berpengaruh terhadap pelaksanaan perilaku hidup bersih dan sehat di sekolah. Semakin positif sikap seseorang maka semakin baik perilakunya.

Berdasarkan sebaran pernyataan diatas didapatkan bahwa mayoritas responden menjawab dengan setuju tentang membuang sampah harus pada tempatnya serta mencuci tangan harus di air yang mengalir. Perilaku membuang sampah pada tempatnya merupakan contoh perilaku yang paling banyak disosialisasikan baik terintegrasi dalam mata pelajaran atau diluar seperti penyuluhan penyuluhan sehingga disinyalir responden sudah memahami dan memilih sikap positif atau setuju dengan perilaku membuang sampah pada tempatnya.

Pernyataan lain yang paling banyak di jawab setuju adalah perilaku mencuci tangan menggunakan air bersih dan sabun. Hal ini sesuai dengan teori bahwa kebersihan diri terutama dalam hal perilaku mencuci tangan setiap makan, merupakan sesuatu yang baik. Teknik dasar yang paling penting dalam pencegahan dan pengontrolan penularan infeksi adalah mencuci tangan. Mencuci tangan adalah menggosok dengan sabun secara bersama seluruh kulit permukaan tangan dengan kuat dan ringkas yang kemudian dibilas untuk membuang air. Tujuannya adalah untuk membuang kotoran dan organism yang menempel di tangan dan untuk mengurangi jumlah mikroba total pada saat itu. Tangan yang terkontaminasi merupakan penyebab utama perpindahan infeksi. Anak sering bermain dengan tanah atau batu dan bermain di tempat-tempat yang kurang bersih seperti selokan. Ada cara lain yang cukup "ampuh" yang dapat menghindarkan anak dari kuman-kuman penyakit yaitu dengan kebiasaan mencuci tangan (Jawapos, 2010).

Mencuci tangan yang benar menurut Hartanto (2009) adalah dengan menggunakan sabun yang dapat membantu menghilangkan kuman yang tidak tampak, miyak, lemak dan kotoran di permukaan kulit. Menggunakan sabun dalam mencuci tangan sebenarnya menyebabkan orang harus mengalokasikan waktunya lebih banyak saat mencuci tangan (kurang lebih 20 detik), namun penggunaan sabun menjadi efektif karena lemak dan kotoran yang menempel akan terlepas saat tangan digosok dan bergesek dalam upaya melepasnya.

Menurut Garner dan Fayero (1986), dalam Potter dan Perry (2005), mencuci tangan paling sedikit 10-15 detik akan memusnahkan mikroorganisme transient paling banyak dari kulit, jika tangan tampak kotor, dibutuhkan waktu yang lebih lama.

Mencuci tangan secara rutin dapat dilakukan dengan menggunakan sabun dalam berbagai bentuk yang sesuai (batang,lembaran, cair atau bubuk). Penggunaan sabun antimikroba dianjurkan untuk mengurangi jumlah mikroba total di tangan. Terdapat banyak jenis sabun antimikroba efektif, termasuk klorheksidin glukonat (CHG), hibiscrub atau salvon 1\%, alcohol, alcohol dan iodofor. Sabun antimikroba tertentu dapat mengiritasi kulit, dan kebutuhan terhadap sabun antimikroba harus dievaluasi terhadap potensi iritasi kulit.

Sedangkan untuk pernyataan yang salah dijawab setuju adalah tentang jamban sehat itu jamban yang wangi dan gemuk menandakan gizi baik. Pernyataan yang salah terkait jamban sehat itu adalah jamban yang wangi mayoritas dijawab salah oleh responden. Jamban sehat adalah jamban adalah suatu ruangan yang mempunyai fasilitas pembuangan tinja manusia. Jamban 
terdiri atas tempat jongkok atau tempat duduk dengan leher angsa atau tanpa leher angsa (cemplung) yang dilengkapi dengan unit penampungan kotoran dan air untuk membersihkannya, (Abdullah, 2010).

Berdasarkan Keputusan Menteri Kesehatan No.852 Tahun 2008 tentang Strategi Nasional Sanitasi Total Berbasis Masyarakat, jamban sehat adalah suatu fasilitas pembuangan tinja yang efektif untuk memutuskan mata rantai penularan penyakit.

Menurut kriteria Depkes RI (1985), syarat sebuah jamban keluarga dikatagorikan jamban sehat, jika memenuhi persyaratan sebagai berikut :

1. Tidak mencemari sumber air minum, untuk itu letak lubang penampungan kotoran paling sedikit berjarak 10 meter dari sumur (SPT SGL maupun jenis sumur lainnya). Perkecualian jarak ini menjadi lebih jauh pada kondisi tanah liat atau berkapur yang terkait dengan porositas tanah. Juga akan berbeda pada kondisi topografi yang menjadikan posisi jamban diatas muka dan arah aliran air tanah.

2. Tidak berbau serta tidak memungkinkan serangga dapat masuk ke penampungan tinja. Hal ini misalnya dapat dilakukan dengan menutup lubang jamban atau dengan sistem leher angsa.

3. Air seni, air pembersih dan air penggelontor tidak mencemari tanah di sekitarnya. Hal ini dapat dilakukan dengan membuat lantai jamban dengan luas minimal $1 \times 1$ meter, dengan sudut kemiringan yang cukup kearah lubang jamban.

4. Mudah dibersihkan, aman digunakan, untuk itu harus dibuat dari bahan-bahan yang kuat dan tahan lama dan agar tidak mahal hendaknya dipergunakan bahan-bahan yang ada setempat;

5. Dilengkapi dinding dan atap pelindung, dinding kedap air dan berwarna terang;

6. Cukup penerangan;
7. Lantai kedap air;

8. Luas ruangan cukup, atau tidak

terlalu rendah;

9. Ventilasi cukup baik, dan

10. Tersedia air dan alat pembersih.

Diperlukan upaya untuk meluruskan persepsi atau pemahaman yang salah tentang ciri jamban yang sehat tidak hanya dilihat dari wangi tidaknya jamban melainkan dari segi luas, ventilasi, jauh dari sumber pencemaran serta kemudahan dalam membersihkannya.

Pernyataan lain yang banyak dijawab salah diantaranya kegemukan menandakan gizi yang baik. Hal ini tidak sesuai dengan teori bahwa gizi baik adalah keadaan dimana asupan zat gizi sesuai penggunaan untuk aktifitas tubuh. Hal ini diwujudkan dengan adanya keselarasan antara tinggi badan terhadap umur, berat badan terhadap umur dan tinggi badan terhadap berat badan. Tingkat kesehatan gizi yang baik ialah kesehatan gizi optimum.

Menurut Ikatan Dokter Anak Indonesia (IDAI), obesitas merupakan keadaan indeks massa tubuh (IMT) anak yang berada di atas persentil ke - 95 pada grafik tumbuh kembang anak sesuai jenis kelaminnya. Definisi ini relatif sama dengan Institute of Medicine (IOM)di AS, sementara Center for Disease Control (CDC) AS mengkategorikan anak tersebut sebagai 'overweight'. CDC berargumen bahwa seorang anak dikategorikan obesitas jika mengalami kelebihan berat badan di atas persentil ke-95 dengan proporsi lemak tubuh yang lebih besar dibanding komponen tubuh lainnya (Andra, 2009)

Menurut Clement dan Ferre
(2003), seorang anak yang
mempunyai kelebihan lemak tubuh
atau mempunyai BMI lebih dari 30.
Kelebihan ini disebabkan banyaknya
makanan yang masuk dibandingkan
energi yang dikeluarkan. BMI dihitung


dengan mengukur berat tubuh dalam kilogram dibagi dengan kuadrat tinggi badan dalam meter. Bila nilai BMI sudah didapat, hasilnya dibandingkan dengan ketentuan berikut :

Nilai BMI $<18,5=$ Berat badan di bawah normal

Nilai BMI 18,5 -22,9 = Normal

Nilai BMI 23,0 - 24,9 = Normal Tinggi

Nilai BMI 25,0 -29,9= di atas normal

Nilai BMI $>=30,0=$ Obesitas

Obesitas adalah kelebihan

berat badan sebagai akibat dari penimbunan lemak tubuh yang berlebihan. Setiap orang memerlukan sejumlah lemak tubuh untuk menyimpan energi, sebagai penyekat panas, penyerap guncangan dan fungsi lainnya.

Rata- rata wanita memiliki lemak tubuh yang ebih banyak dibandingkan pria. Perbandingan yang normal antara lemak tubuh dengan berat badan adalah sekitar $25-30 \%$ pada wanita dan $18-23 \%$ pada pria. Wanita dengan lemak tubuh lebih dari $30 \%$ dan pria dengan lemak tubuh lebih dari $25 \%$ dianggap mengalami obesitas.

Seseorang yang memiliki berat badan 20\% lebih tinggi dari nilai tengah kisaran berat badannya yang normal dianggap mengalami obesitas. Obesitas digolongkan 5 menjadi 3 kelompok: Obesitas ringan

: kelebihan berat badan $20-40 \%$, obesitas sedang : kelebihan berat badan $41-100 \%$ dan obesitas berat: kelebihan berat badan $>100 \%$. Obesitas berat ditemukan sebanyak $5 \%$ dari antara orang-orang yang gemuk.

Dibutuhkan upaya untuk meningkatkan atau menumbuhkan sikap positif terhadap PHBS sekolah melalui kegiatan penyuluhan secara rutin, sosialisasi informasi kesehatan dengan berbagai media yang menarik disesuaikan dengan usia responden.

\section{Peran media permainan ular tangga PHBS Sekolah}

Berdasarkan tabel 5.6

didapatkan bahwa rata rata nilai responden pengetahuan baik adalah 10,15 dengan standar deviasi 1,322. Sedangkan rata rata nilai responden dengan pengetahuan cukup adalah 9,26 dengan standar deviasi 1,163.

Hasil uji statistik didapatkan nilai $\mathrm{p}=0.000$, berarti pada alpha $5 \%$ artinya terdapat perbedaan yang signifikan rata rata nilai sebelum dan sesudah permainan ular tangga PHBS sekolah. Berdasarkan hasil penelitian didapatkan pengaruh media ular tangga terhadap perubahan pengetahuan responden terlihat dari nilai $\mathrm{p} 0,000<$ dari 0,05 artinya terdapat perbedaan yang signifikan antara pengetahuan sebelum dan sesudah permainan ular tangga.

Sedangkan untuk sikap berdasarkan tabel 5.8 didapatkan bahwa rata rata nilai sikap positif responden adalah 5,13 dengan standar deviasi 0,067 . Sedangkan rata rata nilai sikap negatif responden adalah 4,14 dengan standar deviasi 1,069. Hasil uji statistik didapatkan nilai $\mathrm{p}=0.001$, berarti pada alpha $5 \%$ artinya terdapat perbedaan yang signifikan rata rata sikap responden sebelum dan sesudah permainan ular tangga PHBS sekolah. Berdasarkan hasil penelitian didapatkan bahwa perbedaan sikap responden sebelum dan sesudah permainan ular tangga dilihat dari nilai $p$ yaitu $0.001<$ dari 0.05 artinya terdapat perbedaan yang signifikan antara sikap sebelum dan sesudah permainan ular tangga PHBS sekolah.

Tentunya dalam kesuksesan sebuah promosi kesehatan media promosi memegang peranan yang sangat penting dan dapat diartikan sebagai alat bantu yang turut meperlancar komunikasi dan penyebarluasan informasi. Menurut Notoatmodjo (2007), disebut sebagai media promosi kesehatan karena alatalat merupakan saluran untuk 
menyampaikan informasi kesehatan dan untuk mempermudah penerimaan pesan-pesan kesehatan bagi masyarakat atau klien.

Berdasarkan fungsinya sebagai penyalur pesan-pesan kesehatan, media promosi kesehatan ini dibagi menjadi tiga, yakni media cetak, media elektronika, dan media papan. Penggunaan leaflet, poster, film dan power point adalah contoh media yang lazim digunakan dan diharapkan dapat menarik minat anak-anak usia sekolah dasar sehingga mampu menumbuhkan perilaku hidup sehat.

Seperti diuraikan dalam

Notoatmodjo (2007), berdasarkan penelitian para ahli, indra yang paling banyak menyalurkan pengetahuan ke dalam otak adalah mata. Kurang lebih 75\% sampai $87 \%$ dari pengetahuan manusia diperoleh dan disalurkan melalui mata. Sedangkan $13 \%$ sampai $25 \%$ lainnya tersalur melalui indra yang lain.

Untuk meningkatkan

kesehatan anak usia sekolah diperlukan upaya sosialisasi kegiatan perilaku hidup bersih dan sehat di sekolah melalui rancangan media pendidikan yang menarik sehingga pesan yang disampaiakan bisa mudah diterima oleh siswa. Hal ini dikarenakan anak sekolah memiliki karakter yang khas dan unik baik secara fisik maupun mental, oleh karena itu strategi dan metode pengajaran yang diterapkan harus sesuai dengan kekhasan anak yaitu dengan strategi bermain sambil belajar atau belajar seraya bermain. Bermain merupakan sarana untuk menggali pengalaman belajar yang sangat berguna untuk anak. Bermain juga dapat menjadi sarana untuk mengembangkan kreativitas dan daya cipta , karena bermain adalah sumber pengalaman dan uji coba. Bermain dari segi pendidikan adalah kegiatan permainan menggunakan alat permainan

G. mendidik serta alat yang bisa merangsang perkembangan aspek kognitif, emosi, sosial, dan fisik yang dimiliki anak.

Permainan ular tangga PHBS di sekolah adalah permainan untuk anak sekolah dengan berbagai pesan sesuai dengan indicator PHBS di sekolah seperti perilaku personal hygiene, keutamaan olah raga teratur, larangan merokok dan napza, pemberantasan sarang nyamuk, jamban sehat, air bersih, cuci tangan pake sabun, membuang sampah, jajanan sehat serta pengukuran berat badan dan tinggi badan. Permainan ular tangga adalah permainan papan untuk anak-anak yang dimainkan oleh 2 orang atau lebih. Papan permainan dibagi dalam kotakkotak kecil dan di beberapa kotak digambar sejumlah "tangga" atau "ular yang menghubungkannya dengan kotak lain. Permainan ini diciptakan pada tahun 1870. Setiap pemain mulai dengan bidaknya di kotak pertama (biasanya kotak di sudut kiri bawah) dan secara bergiliran melemparkan dadu. Bidak dijalankan sesuai dengan jumlah mata dadu yang muncul. Bila pemain mendarat di ujung bawah sebuah tangga, mereka dapat langsung pergi ke ujung tangga yang lain. Bila mendarat di kotak dengan ular, mereka harus turun ke kotak di ujung bawah ular. Pemenang adalah pemain pertama yang mencapai kotak terakhir. (Wikipedia : 2010)

\section{F. SIMPULAN DAN SARAN}

Kesimpulan dari penelitian ini adalah : 
1. Rata rata nilH.pengetahuan siswa sebelum adalah 9.94 dengan standar deviasi 1.337. Nilai terendah adalah 7 dan nilai paling tinggi adalah 13.

2. Rata rata nilai pengetahuan responden tentang PHBS Sekolah adalah 16,6 dengan standar deviasi 1,638. Nilai paling rendah pengetahuan responden adalah 12 dan nilai paling tinggi responden adalah 20.

3. Hasil uji statistik didapatkan nilai $\mathrm{p}$ $=0.000$, berarti pada alpha $5 \%$ artinya terdapat perbedaan yang signifikan rata rata nilai sebelum dan sesudah permainan ular tangga PHBS sekolah.

4. Berdasarkan hasil analisis didapatkan rata rata nilai sikap responden sebelum permainan ular tangga adalah 5.06 dengan standar deviasi 0.742 . Nilai terendah adalah 2 dan nilai paling tinggi adalah 7 .

5. Berdasarkan tabel 5.8 didapatkan bahwa rata rata nilai sikap positif responden adalah 5,13 dengan standar deviasi 0,067 . Sedangkan rata rata nilai sikap negatif responden adalah 4,14 dengan standar deviasi 1,069 .

6. Hasil uji statistik didapatkan nilai $\mathrm{p}$ $=0.001$, berarti pada alpha $5 \%$ artinya terdapat perbedaan yang signifikan rata rata sikap responden sebelum dan sesudah permainan ular tangga PHBS sekolah.

Saran yang direkomendasikan Dapat memberikan dukungan penuh dalam penerapan PHBS sekolah dengan membuat

\section{H. DAFTAR PUSTAKA}

Notoatmodjo, S. (2009). Pendidikan Promosi dan Perilaku Kesehatan. Jakarta: FKM UI.

------------------. (2010). Metode

Penelitian Kesehatan. Jakarta: Rineke Cipta. -.(2011).

Pendidikan dan Perilaku Kesehatan. Jakarta: Rhineka Cipta.

Metodelogi Penelitian Kesehatan. Jakarta: Rineka Cipta. -(2011). Promosi

Kesehatan dan Ilmu Perilaku. Jakarta: Rineke Cipta.

Azwar, S. (2012). Sikap Manusia, Teori dan Pengukurannya. Yogyakarta : Pustaka Pelajar offset.

Departemen Kesehatan RI, 2012. Sekolah Dengan Perilaku Hidup Bersih dan Sehat.

Dinas Kesehatan Provinsi Jawa barat, 2012. Buku Saku Pelaksanaan PHBS Bagi sekolah

Bahar. Armasastra, "Paradigma Baru Pencegahan Karies Gigi”, Fakultas Ekonomi Universitas Indonesia,

Jakarta, 2011

Departemen Kesehatan RI, "Pedoman Upaya Kesehatan Gigi Masyarakat (UKGM)",Cetakan Kedua, Departemen Kesehatan, Jakarta, 2000

Kawuryan, R., "Hubungan pengetahuan tentang kesehatan gigi dan mulut dengan kejadian karies gigi anak

SDN Kleco II Kelas V dan VI Kecamatan Laweyan”, Skripsi, UMS, Surakarta, 2008.

Najma, SKM, MPH, "Managemen dan Analisis Data Kesehatan", Yogyakarta, 2011 Nuha Medika,

Notoatmodjo, Soekidjo, "Metode Penelitian Kesehatan" Rineka Cipta, Jakarta,2010

kebijakan dan pereneanaan kegiatan PH'MStodelogi se Penelitian Kesehatan", Rineka Cipta, Jakarta, 2002

Forum Ilmiah Volume 12 Nomor 1, Januari 201576 Usia Sekolah Di Madrasah Ibtidaiyah Al-Istiqomah Tangerang”, Skripsi, Fakultas Keperawatan Universitas Indonesia, Jakarta, 2012 
Ramadhan, Ardyan Gilang, "Serba Serbi Kesehatan Gigi dan Mulut", Bukune, Jakarta, 2010

Sri Gupta, A. A., "Perawatan Gigi dan Mulut", Cetakan Pertama, Penerbit Prestasi Pustaka Publisher, Jakarta, 2004

Sugiyono, "Metode Penelitian Kuantitatif Kualitatif dan R\&D", Alfabeta, Bandung, 2007

Aggoun, Y. 2007. Obesity, metabolic syndrom, and cardiovascular isease. Pediatric Research 61(6): 653659

Andra. 2007. Sindrom metabolik usia dini. Racikan Utama 6(10): 1-3

Atabek, M.M., O. Pirgon and

A.S. Kivrak. 2007. Evidence for association between insulin resistance and premature caroid rtherosclerosis in childhood obesity. Pediatric Research 61(3): 345-349

Clement, K. And P. Ferre. 2003. Genetics and the pathophysiology of obesity. Pediatric Research 53(5): 721725Katier, N.V.P.,R.P. Rooman, L.Haas, S.L. Verhulst, K.N. Desager, J. Ramet and B.E.

Suys. 2008. Early cardiac abnormalities in obese children: Importance of obesity per se versus associated cardiovascular risk factor. Pediatric Research 64(2): 205209Kriemler, S., H. Hebestreit, S. Mikami, T. Bar-or, B. Ayub and O. Bar-or. 1999. Impacf of a single exercise bout on energy expenditure and spontaneous physical activity of $\mathrm{C}$. Pediatric Research 46(1): 40-44

Pudjiadi, S. 1982. Obesitas pada anak. Cermin Dunia Kedokteran 27:1517

Suharjo. 1989. Pemberian Makanan pada Bayi dan Anak. PAU Pangan dan Gizi IPB, Bogor

Warner, J.T., W. Bell, D.Webb K.H., J.W. Gregory. 1998. Daily energy expenditure and physical activity in survivors of childhood malignancy. Pediatric Research 43(5): 607-613 